\title{
Effect of proline and salicylic acid on germination and antioxidant enzymes at different temperatures in Muskmelon (Cucumis melo L.) seeds
}

\author{
Sandeep Kaur* and Namarta Gupta \\ Department of Botany, Punjab Agricultural University, Ludhiana -141001 (Punjab), INDIA \\ *Corresponding author. E-mail: sandeepbajwa1994@gmail.com \\ Received: October 15, 2016; Revised received: April 19, 2017; Accepted: October 5, 2017
}

\begin{abstract}
Effect of different seed treatments hydration, warm water, proline $(10 \mathrm{mM}$ and $20 \mathrm{mM})$ and salicylic acid $(0.1 \mathrm{mM}$ and $0.5 \mathrm{mM})$ was investigated on percent germination and activity of antioxidant enzymes viz. superoxide dismutase (SOD), catalase (CAT) and peroxidase (POX) at different temperatures in Muskmelon (Cucumis melo L.) seeds. It was observed that lower temperature $\left(20^{\circ} \mathrm{C}\right)$ had decreased seed germination and activity of various antioxidant enzymes. Various seed treatments increased percent germination and activity of these enzymes as compared to control at both the temperatures. Proline $20 \mathrm{mM}(96.6)$ and SA $0.1 \mathrm{mM}(91.6)$ showed better results as compared to proline $10 \mathrm{mM}(95.0)$ and salicylic acid $0.5 \mathrm{mM}(86.6)$ respectively. Thus proline and salicylic acid play an ameliorating role on low temperature stress by enhancing the activities of antioxidant enzymes and scavenging the free radicals.
\end{abstract}

Keywords: Antioxidant enzymes, Low temperature, Muskmelon, Proline, Salicylic acid

\section{INTRODUCTION}

Muskmelon (Cucumis melo L.) is one of the major vegetable crop in the world and belongs to the family Cucurbitaceae (Sensory et al.,2007). It contains calcium, phosphorus, vitamin $\mathrm{A}$ and $\mathrm{C}$ and is a famous summer fruit. Poor seed germination is a common phenomenon at sub-optimal temperature which causes a great concern for growers who grow this crop in the month of February. Temperature stress affects many physiological and biochemical processes and induces molecular mechanisms and gene expression to modulate plant responses (Siboza et al., 2014). Chilling stress, defined as the temperature in a range low enough to suppress growth without ceasing cellular functions, is known to induce several abnormalities at various levels of cell organization (Balestrasse et al.,2010). Low temperature induces the reduction in percent germination, vigor and the growth of seedlings and it also causes oxidative stress in tissues and generation of reactive oxygen species (ROS) and it increases the level of the non-enzymatic antioxidants (Airaki et al., 2011).The adverse effect of low temperature can be mitigated by treating the seeds with different chemicals i.e. proline and salicylic acid. Proline is a proteinogenic amino acid with an exceptional conformational rigidity and is essential for primary metabolism and its exogenous application enhanced stress tolerance at low concentrations (Hayat et al., 2012). Proline accumulation is important for the tolerance of certain adverse environmental conditions and it is an important regulator of cellular ROS balance. Salicylic acid is naturally occurring phenolic compound and endogenously synthesized signaling molecule in plants. It is involved in the regulation of growth and development of plants as well as their responses to biotic and abiotic stress factors (Miura and Tada 2014). The present study was undertaken with the objective to evaluate the effect of seed treatments on percent germination and activities of antioxidant enzymes at low temperature.

\section{MATERIALS AND METHODS}

The experiment was carried out at the PG laboratory, Department of botany, Punjab agricultural university, Ludhiana .The seeds of muskmelon (Cucumis melo L.) c.v. Punjab Sunehri were procured from department of vegetable science, PAU Ludhiana and used for observations on percent germination and estimation of different antioxidant enzymes. There were six seed treatments viz. hydration, warm water soaking, proline $10 \mathrm{mM}$, proline $20 \mathrm{mM}$, salicylic acid $0.1 \mathrm{mM}$ and salicylic acid $0.5 \mathrm{mM}$. The seeds were surface sterilized by dipping in 0.1 percent mercuric chloride and washed twice with distilled water and then dried on filter paper. Then the treatments were given by soaking the seeds in different concentrations of proline and salicylic acid. After seed treatments, seedlings were raised by placing the seeds on top of the germination paper in seed germinator for 8 days at $20^{\circ} \mathrm{C}$ and $25^{\circ} \mathrm{C}$. Eight days old seedlings were used to calculate percent germination by following ISTA rules Anonymous (2008).

Percent germination $=$ No. of seeds germinated $/$ Total no. of seeds x 100 
The activity of catalase (Chance and Maehly 1955), peroxidase (Shannon et al., 1966) and superoxide dismutase (Marklund and Marklund, 1974) were recorded.

Catalase enzyme (Chance and Maehly, 1955): To $1.9 \mathrm{ml}$ of chilled $0.1 \mathrm{M}$ sodium phosphate buffer (pH7.0) added $0.1 \mathrm{ml}$ of the enzyme extract. The reactionwas started by adding $1 \mathrm{ml}$ of $\mathrm{H} 2 \mathrm{O} 2$ to the reactionmixture. The absorbance was recorded at 240 $\mathrm{nm}$ for 1 minute at an intervals of 30 second. Enzyme activity

was expressed as $\mu$ moles of $\mathrm{H}_{2} \mathrm{O}_{2}$ decomposed $/ \mathrm{min} /$ gFW using 0.0394 as extinction coefficient.

Peroxidase enzyme (Shannon et al., 1966): Enzyme extract $0.1 \mathrm{ml}$ was added to $3 \mathrm{ml}$ of chilled guaiacol. Addition of $0.1 \mathrm{ml}$ of $\mathrm{H}_{2} \mathrm{O}_{2}$, started the reaction and the rate of decrease in absorbance was read at $470 \mathrm{~nm}$ at 30 seconds intervals for 3 minutes. The activity is expressed as units/min/g FW.

Superoxide dismutase enzyme (Marklund and Marklund, 1974): To a cuvette, added $1.5 \mathrm{ml}$ of Tris$\mathrm{HCl}$ buffer ( $\mathrm{pH} 8.2), 0.5 \mathrm{ml}$ of $6 \mathrm{mM}$ EDTA, $1 \mathrm{ml}$ of 6 $\mathrm{mM}$ pyrogallol solution and $0.1 \mathrm{ml}$ of enzyme extract. Absorbance at $420 \mathrm{~nm}$ after an interval of 30 seconds was recorded upto 3 minutes. The activity is expressed as units/min/g FW.

Statistical analysis: The data was statistically analyzed by using CPCSI software.

\section{RESULTS AND DISCUSSION}

Percent germination: During the present investigation, it was observed that percent germination was less at $20^{\circ} \mathrm{C}$ than $25^{\circ} \mathrm{C}$ (Table 1). Hydration and Warm water $\left(45^{\circ} \mathrm{C}\right)$ treatment of seeds for 10 minutes increased the germination as compared to control. At $20^{\circ} \mathrm{C}$ and $25^{\circ} \mathrm{C}$, the seeds treated with proline $10 \mathrm{M}$ and $20 \mathrm{mM}$ increased percent germination compared to control. Different concentrations of salicylic acid (SA) also showed an increase in percent germination at both the temperatures. Proline $20 \mathrm{mM}$ and SA $0.1 \mathrm{mM}$ showed better results as compared to proline $10 \mathrm{mM}$ and SA $0.5 \mathrm{mM}$ respectively.

Decrease in germination at low temperature may be attributed to increase in the production of ROS in plants (Hodgson and Raison 1991). Increase in germination in the present is also in agreement with the findings of Singh et al. (2016) in Pea and Espanany et al. (2016) in black cumin (Nigella sativa). Attenuation of isoproturon (IPU) toxicity by salicylic acid (SA) was observed by Singh et al. (2016). Salicylic acid (100mg/ L) improved the germination, radicle elongation and dry weight in compared with the control under cadmium stress (Espanany et al., 2016). Shruti et al. (2016) reported similar increase in germination of naturally aged seeds of radish by proline and salicylic acid. Increase in percent germination by hydration, warm water, proline and salicylic acid may be due to metabolic
Table 1. Effect of seed treatments on germination of muskmelon (Cucumis melo L.) seeds.

\begin{tabular}{llc}
\hline \multirow{2}{*}{ Treatment } & \multicolumn{2}{c}{ Percent germination } \\
\cline { 2 - 3 } & $\mathbf{2 5}^{\circ} \mathbf{C}$ & $\mathbf{2 0}^{\circ} \mathbf{C}$ \\
\hline Control & 85.0 & 75.3 \\
Hydration & 88.3 & 78.7 \\
Warm water $\left(45^{\circ} \mathrm{C}, 10 \mathrm{~min}.\right)$ & 86.3 & 79.6 \\
Proline $(10 \mathrm{mM})$ & 95.0 & 86.0 \\
Proline $(20 \mathrm{mM})$ & 96.6 & 88.9 \\
Salicylic acid $(0.1 \mathrm{mM})$ & 91.6 & 87.6 \\
Salicylic acid $(0.5 \mathrm{mM})$ & 86.6 & 83.6 \\
CD at 5\% & 3.90 & 7.60 \\
\hline
\end{tabular}

repair during imbibitions (Bray et al., 1989), a buildup of germination-enhancing metabolites (Basra et al., 2005) and osmotic adjustment under abiotic stress conditions (Hyun et al., 2003). SA improved drought and chilling stress tolerance in wheat (Triticum aestivum L.) by protecting the structure of plant cell under low temperature (Horvath et al., 2007). Proline has an important role in increasing the germination as well as resistance to various stresses by enhancing the activities of antioxidant enzymes (Agami 2014). Salicylic acid at 50 and $100 \mathrm{mg} / \mathrm{L}$ when applied to seeds under low temperature (at $24^{\circ} \mathrm{C}$ and $19^{\circ} \mathrm{C}$ with day and night length of $15 / 9 \mathrm{~h}$ ) conditions improved the germination rate in cucurbits (Rehman et al., 2011). Salicylic acid may be involved in improving the rate of germination because it induces the activities of enzymes involved in germination of Arabidopsis seeds (Rajjou et al., 2006). The increased percent germination in present results corroborates with the the findings of Talat (2013) who reported that application of proline (100 $\mathrm{mM}$ ) increased the percent germination in wheat. Lee and Hong (2002) suggested that salicylic acid (0.5 and $1.0 \mathrm{mM}$ ) promotes percent germination in cucumber

Antioxidant enzymes: Antioxidant enzymes such as catalase (CAT), peroxidase (POD) and superoxide dismutase (SOD) have a main role in scavenging of the ROS.

Catalase activity $(\Delta \mathrm{A} / \mathrm{min} / \mathrm{g}$ FW $)$ : Different treatments increased the activities of antioxidant enzymes at $25^{\circ} \mathrm{C}$ and $20^{\circ} \mathrm{C}$ (Table 2). Hydration of seeds for 6 hrs and warm water treatmentincreased the catalase activity over control at both the temperatures. Both the concentrations of proline enhanced the activity of catalase as compared to control at $25^{\circ} \mathrm{C}$ and $20^{\circ} \mathrm{C}$ Proline $20 \mathrm{mM}$ showing better results. Similarly SA 0.1 and $0.5 \mathrm{mM}$ also improved the catalase activity over SA $0.5 \mathrm{mM}$ and control at both the temperatures SA 0.1 $\mathrm{mM}$ being more effective.

Peroxidase $(\Delta \mathbf{A} / \mathbf{m i n} / \mathbf{g} \mathbf{F W})$ : Different seed treatments increased the peroxidase activity at both the temperatures. (Table 2). At $20{ }^{\circ} \mathrm{C}$ and $25^{\circ} \mathrm{C}$, hydration and warm water enhanced the activity of peroxidases as compared to control. Both the concentrations of proline and salicylic acid were effective for increasing 
Table 2. Effect of seed treatments on antioxidant activities of muskmelon (Cucumis melo L.) seedlings.

\begin{tabular}{|c|c|c|c|c|c|c|}
\hline \multirow[t]{2}{*}{ Treatments } & \multicolumn{2}{|c|}{$\begin{array}{c}\text { Catalase }(\Delta \mathrm{A} / \mathrm{min} / \mathrm{g} \\
\text { FW) }\end{array}$} & \multicolumn{2}{|c|}{$\begin{array}{c}\text { Peroxidase }(\Delta \mathrm{A} / \\
\mathrm{min} / \mathrm{g} \mathbf{F W})\end{array}$} & \multicolumn{2}{|c|}{$\begin{array}{c}\text { Superoxide dismutase } \\
(\Delta \mathrm{A} / \mathrm{min} / \mathbf{g} \mathbf{F W})\end{array}$} \\
\hline & $25^{\circ} \mathrm{C}$ & $20^{\circ} \mathrm{C}$ & $25^{\circ} \mathrm{C}$ & $20^{\circ} \mathrm{C}$ & $25^{\circ} \mathrm{C}$ & $20^{\circ} \mathrm{C}$ \\
\hline Control & 46.83 & 39.79 & 4.41 & 2.53 & 58.2 & 50.8 \\
\hline Hydration & 48.37 & 44.08 & 5.55 & 2.75 & 62.0 & 53.1 \\
\hline Warm water $\left(45^{\circ} \mathrm{C}, 10 \mathrm{~min}.\right)$ & 51.25 & 45.79 & 5.67 & 3.63 & 68.2 & 54.8 \\
\hline Proline $(10 \mathrm{mM})$ & 56.29 & 53.06 & 7.6 & 5.83 & 75.4 & 60.9 \\
\hline Proline $(20 \mathrm{mM})$ & 59.33 & 54.14 & 8.73 & 6.18 & 79.1 & 63.2 \\
\hline Salicylic acid (0.1mM) & 60.69 & 50.11 & 5.97 & 5.45 & 69.3 & 61.5 \\
\hline Salicylic acid $(0.5 \mathrm{mM})$ & 61.01 & 52.78 & 5.64 & 5.03 & 64.2 & 58.4 \\
\hline CD at $5 \%$ & 1.15 & 1.03 & 0.70 & 1.35 & 0.67 & 1.29 \\
\hline
\end{tabular}

the peroxidase activity. The effect of proline $20 \mathrm{mM}$ and salicylic acid $0.1 \mathrm{mM}$ was better as compared to of proline $10 \mathrm{mM}$ and salicylic acid $0.5 \mathrm{mM}$.

Superoxide dismutase $(\Delta \mathbf{A} / \mathbf{m i n} / \mathbf{g}$ FW): Hydration and warm water treatment increased the superoxide dismutase activity and over control (Table 2). Seeds treated with proline and salicylic acid had more superoxide activity as compared to control. The effect of proline $20 \mathrm{mM}$ was more as compared to proline $10 \mathrm{mM}$. SA 0.1 and SA $0.5 \mathrm{mM}$ improved the activity over control at $20^{\circ} \mathrm{C}$ and $25^{\circ} \mathrm{C}$. Treatment of seeds with salicylic acid also improved the superoxide dismutase activity of seedlings as SA $0.1 \mathrm{mM}$ increased the superoxide activity more as compared to SA $0.5 \mathrm{mM}$.

It was observed that low temperature decreased the activities of antioxidant enzymes.Catalase activity was decreased in avocado fruit (Sharon and Kahn 1979) and cucumber leaves (Omran 1980) during chilling. It leads to the production of free radicals. Superoxide and hydrogen peroxide produced in plant tissues exposed to low temperature may cause the peroxidation of membrane lipids Murugan and Iyer, 2016) Increase in the activity of CAT, POX and SOD by proline and salicylic acid may be attributed to their role in scavenging the free radicals produced by low temperature. Proline acts as a scavenger of reactive oxygen species (Signorelli et al., 2013; Das and Roychoudhary, 2014). Seed priming with salicylic acid triggered the activities of superoxide dismutase, peroxidase, and catalase, and enhanced the accumulations of glutathione and free proline in rice seedlings and help to prevent the rice seedlings from chilling induced oxidative stress. (Hussain et al., 2016).The exogenous application of SA significantly $(\mathrm{P}<0.05$, ANOVA) increased the POD and CAT activities. SA treatment eliminates the accumulation of $\mathrm{H}_{2} \mathrm{O}_{2}$ in leaves under chilling stress (Zhou et al 2006). Mutlu et al. (2016) reported that exogenous SA $(0.1 \mathrm{mM})$ could play an ameliorating role on cold tolerance by regulating reactive oxygen species and the activities of antioxidative enzymes in both cold-sensitive and cold-toleran tcultivars of barley. Zhang et al., (2016) reported that Chilling stress resulted in greater induction of SA levels in the chilling-tolerant cultivar Changchun mici in both leaves and seeds compared to the chilling-sensitive one Beijing jietou, while the former one contained higher levels of SA than the latter one in the seeds under normal conditions. Moreover, exogenous application of SA increased significantly the POD and CAT activities and soluble protein content and that exogenous SA can enhance the chilling tolerance ability, which might be achieved through modulating the antioxidant system in cucumber. Chen et al ( 2016) proposed the role of SA and enzymes CAT and POX in providing resistance against powdery mildew in wheat. It was reported by Yusuf et al (2008) that the toxic effects generated by the lower concentration of $\mathrm{NaCl}(50 \mathrm{mmol} / \mathrm{L})$ were completely overcome by the application of SA $(10 \mathrm{uM} /$ 1) increasing the peroxidase activity. The increased activity of POD and CAT was correlated with chilling tolerance in cucumber (Kang and Saltveit 2001). SOD can catalyze the dismutation of $\mathrm{O}_{2}^{-}$into oxygen $\left(\mathrm{O}_{2}\right)$ and $\mathrm{H}_{2} \mathrm{O}_{2}$ to control lipid oxidation and protect membrane systems from being oxidized by ROS. Exogenous SA treatments enhanced the SOD activity significantly (at $\mathrm{CD} 5 \%$ ) and it improves the plant growth and development, flowering, ion uptake, stomatal regulation and photosynthesis (Kadioglu et al., 2011). Exogenous application of proline improves the functioning of peroxidase (Yan et al., 2011) and catalase (Ali et al., 2014) enzymes. Similar results were also reported by Yusuf et al., (2008) in mustard, Shruti and Gupta (2015) in radish and Kaur and Gupta (2015) in Cucumber.

\section{Conclusion}

It is evident that different seed treatments increased the germination and activities of antioxidant enzymes at both the temperatures. But among all the treatment of proline $20 \mathrm{mM}$ and salicylic acid $0.1 \mathrm{mM}$ showed better results over other seed treatments and thus provide tolerance to low temperature by scavenging the free radicals. Thus Proline $20 \mathrm{mM}$ amd SA $0.1 \mathrm{mM}$ increased percentage germination by scavenging the free radicals produced as indicated by the increased activities of the antioxidant enzymes viz. CAT, POX and SOD. Thus proline and SA can be used to reduce the adverse effects produced by low temperature stress. 


\section{REFERENCES}

Agami, R.A. (2014). Application of ascorbic acid and proline increase resistance to salt stress in barley seedlings. Journal of Plant Biology, 58: 341-347

Airaki, M., Leterrier, M., Mateos, R.M., Valderrama, R., Chaki, M. and Barroso, J.B. (2011). Metabolism of reactive oxygen species and reactive nitrogen species in pepper (Capsicum annuum L.) plants under low temperature stress. Plant Cell Environment, 34: 365 $-369$

Ali, B., Qian, P., Jin, R., Ali, S., Khan, M., Aziz, R., Tian, T. and Zhou, W. (2014). Physiological and ultra-structural changes in Brassica napus seedlings induced by cadmium stress. Journal of Plant Biology, 58: 131-138

Anonymous (2008). International rules for seed testing. Seed Science Technology, Zurich, Switzerland

Balestrasse, K.B., Tomaro, M.L.,Battle, A. and Noriega, G.O. (2010). The role of 5-aminolevolinic acid in the response of cold stress in soybean plants. Phytochemistry, 71: 2038-2045

Basra S, Farooq M A, Tabassum M R (2005) Physiological and biochemical aspects of seed vigor enhancement treatments in fine rice (Oryza sativa L.). Seed Science Technology, 33: 623-28

Bray, C. M., Davison, P. A., Ashraf, M. and Taylor, R. M. (1989). Biochemical changes during priming of leek seeds. Annual Botany 63: 185-93

Chance, B. and Maehly, A.C. (1955). Assay of catalase and peroxidases. Methods of Enzymology, 2: 764-775

Chen, T., Xiao, J., Xu J.,Wan W.,Qin B., Cao A., ChenW., Xing L., Chen D., Gao X., Zhang S., ZhangR., Shen W., Wang H. and Wang X. (2016) Two members of TaRLK family confer powdery mildew resistance in common wheat. BMC Plant Biology, 16: 27-44

Das, K. and Roychoudhary, A. (2014) Reactive oxygen species (ROS) and response of antioxidants as ROSscavengers during environmental stress in plants. Frontiers in Environmental Sciences, 2: 1-12

Espanany, A. Fallah, S. and Tadayyon, A. (2016) Seed priming improves seed germination and reduces oxidative stress in black cumin (Nigella sativa) in presence of cadmium. Industrial Crop Products, 79: 195-204

Hayat, Q., Hayat, S., Irfan, M. and Ahmed, A. (2012). Effect of exogenous salicylic acid under changing environment: A review. Environmental Experimental Botany, 68: $14-25$

Hodgson, R.A.J. and Raison J.K. (1991). Lipid peroxidation and superoxide dismutase activity in relation to photoinhibition induced by chilling in moderate light. Planta. 185: 215-219

Horvath, E., Szalai, G. and Janda, T. (2007). Induction of abiotic stress tolerance by salicylic acid signalling. Journal of Plant Growth Regulation, 26: 290 -300

Hussain, S., Khan, F., Hussain, H.A. and Nie, L. (2016). Physiological and Biochemical Mechanisms of Seed Priming-Induced Chilling Tolerance in Rice Cultivars. Frontiers in Environmental Sciences, 7: 116-19

Hyun, D.Y., Lee, S.J., Seo, Y.W. and Lee, Y.I. (2003). Selection of Azetidine-2-carboxylic acid resistance cell lines by in vitro mutagenesis in rice (Oryza sativa L.) Journal of Plant Biotechnology, 5:43-49

Kadioglu, A., Saruhan, N., Saglam, A.,Terzi, R. and Acet, T. (2011). Exogenous salicylic acid alleviates effects of long term drought stress and delays leaf rolling by inducing antioxidant system. Plant Growth Regulation, 64:27-37

Kang, H.M. and Saltveit, M.E. (2001). Activity of enzymatic antioxidant defense systems in chilled and heat shocked cucumber seedlings radicles. Plant Physiology, 113: 548 $-556$

Kaur, H. and Gupta, N. (2015). Exogenous application of salicylic acid and proline increase antioxidant enzyme activities at low temperature in cucumber (Cucumis sativus L.) The Journal of Plant Science and Research $31: 217-23$

Lee, G.S. and Hong, J.H. (2002). Effect of Salicylic Acid on Growth and Chilling Tolerance of Cucumber Seedlings. Journal of Environmental Science, 11:1173-1181

Marklund, S. and Marklund, G. (1974). Improvement of superoxide anion radical in the auto-oxidation of Pyrogallol and a convenient assay for superoxide dismutase. European Journal of Biochemistry, 47: 169-174

Miura, K. and Tada, Y. (2014). Regulation of water, salinity and cold stress responses by salicylic acid. Fronteries Journal of Plant Sciences, 5: 4-10

Murugan, K. and Iyer, V. V. (2014). Antioxidant activity and gas chromatographic-mass spectrometric analysis of extracts of the marine algae, Caulerpa peltata and Padina Gymnospora. Indian J Pharm Science, 76:548-552

Mutlu, S., Atici, O., Nalbantoglu, B. and Mete, E. (2016). Exogenous salicylic acid alleviates cold damage by regulating antioxidative system in two barley (Hordeum vulgare L.) cultivars. Frontiers in Life Science, 9: 99109

Omran, R.G. (1980). Peroxide levels of catalase, peroxidase, and indoleacetic acid oxidase during and after chilling cucumber seedlings. Plant Physiology, 65: 407-408

Rajjou, L., Belghazi, M., Huguet, R., Robin, C., Moreau, A., Job, C. and Job, D. (2006). Proteomic investigation of the effect of salicylic acid on Arabidopsis seed germination and establishment of early defense mechanism. Plant Physiology, 141: 910-923

Rehman, H., Farooq, M., Basra, S.M.A. and Afzal, I. (2011). Hormonal priming with salicylic acid improves the emergence and early seedling growth in cucumber. Journal of Agriculture Social Sciences, 7: 109-113

Sensory, S., Ertek, A., Gedik, I. and Kucukyumuk, C. (2007). Irrigation frequency and amount affect yield and quality of field grown melon (Cucumis melo L.). Agriculture Water Management, 88: 269-274

Shannon, L.M., Kay, E. and Lew, J. Y. (1966). Peroxidase isoenzymes from horseradish roots: Isolation and physical properties. Journal of Biology, 241: 2166-2172

Sharon, O. and Kahn, V. (1979). Browning potential, PPO, catalase and acid phosphatase activities during ripening of non-chilled and chilled avocado. Journal of Food Agriculture Science, 30: 634-638

Shruti and Gupta, N. (2015). Effect of Salicylic Acid and Proline on seed germination and antioxidant enzymes in aged seeds of radish (Raphanus sativus L). The Journal of Plant Science and Research, 31: 91-96

Shruti, Gupta, N., and Singh, H. (2016). Effect of Proline and Salicylic Acid on seed vigour parameters in fresh and aged seeds of radish (Raphanus sativus L). Agricultural 
Research Journal, 53: 371-375

Siboza, X. I., Bertling, I., and Odindo, A. O. (2014). Salicylic acid and methyl jasmonate improve chilling tolerance in cold-stored lemon fruit (Citrus limon). Journal of Plant Physiology 171: 1722-1731

Signorelli, S., Coitino, E.L., Borsani, O. and Monza, J. (2013). Molecular mechanisms for the reaction between ${ }^{\circ} \mathrm{OH}$ radicals and proline: insights on the role as reactive oxygen species scavenger in plant stress. The Journal of Physical Chemistry B,118:37-47

Singh, H., Singh, N.B., Singh, A., Hussain, I. and Yadav, V. (2016). Physiological and biochemical effects of salicylic acid on Pisum sativum exposed to isoproturon. Archives of Agronomy and Soil Science, 62 : 1425-1436

Talat, A., Nawaz, K., Hussian, K., Bhatti, H.K., Siddqi, H.E., Khalid, A., Anwer, S. and Sharif, U. (2013). Foliar application of proline for salt tolerance of two wheat (Triticam aestivum L.) cultivars. Journal of Applied Sciences, 22: 547-554
Yan, Z., Guo, S., Shu, S., Sun, J. and Tezuka, T. (2011). Effects of proline on photosynthesis, root reactive oxygen species metabolism in two melon cultivars (Cucumis melo L.) under $\mathrm{NaCl}$ stress. African Journal of Biotechnology, 10: 18381-18390

Yusuf, M., Aiman, H., Barket, A., Shamsul, H., Qazi, F. and Aqil, A. (2008). Effect of salicylic acid on salinityinduced changes in Brassica juncea. Journal of Integrated Plant Biology,50: 1096-1102

Zhang, W.P., Jiang, B., Lou, L.N., Lu, M..H, Yang, M., and Chen, J.F. (2011) Impact of Salicylic acid on the antioxidant enzyme system and hydrogen peroxide production in Cucumis sativus under chilling stress. Zeitschrift Fur Naturfoschung Sect ,66:413-422

Zhou, Y.H., Yu, J.Q., Mao, W.H., Huang, L.F., Song, X.S. and Nogues, S. (2006). Genotypic variation of rubisco expression, photosynthetic electron flow and antioxidant metabolism in the chloroplasts of chill-exposed cucumber plants. Plant Cell Physiology, 47: 192-199 